objects should be defined and the results tested and published." The discussion next week is intended to make these ideas more precise, and the OECD is certainly hoping that a pilot scheme for a project of this sort may be approved.

The final discussion will be on the problems of information retrieval. As well as the technical difficulties of retrieval, there are distinct dangers that the various types of retrieval system now being developed will be incompatible. If the United States devises a retrieval system which Europe is unable to plug into, many of the advantages of the system will be lost.

\section{Not Enough Uranium}

THE rapid expansion of nuclear power has meant that electrical utilities, particularly in the United States, have had to take a hard look at the supplies of uranium. like most mineral resources, the stocks seem to be limited. Some argue that this will enforce a much greater reliance on coal fired stations-or, at the other extreme, on the successful development of fusion reactors. More optimistic observers point out that this fear of shortage is a familiar part of mining operations, without which no mining company would ever feel like prospecting. Between 1935 and 1965, for example, petroleum reserves ranged from ten to fourteen times annual requirements. Despite or, some might argue, because of the potential shortage, exploration kept ahead of demand.

The European Nuclear Energy Agency and the International Atomic Energy Agency have now got together to produce revised estimates of uranium resources. Briefly, the conclusion is that not enough has yet been found. Substantial new reserves are needed if estimated demand is to be met. The report says that "there is no reason to suppose that such deposits will not be found if a massive, well-financed and well-conceived prospecting effort is undertaken. However, the magnitude and urgency of the effort that will be required cannot be too strongly emphasized".

Uranium is widely distributed throughout the world, although Canada, the United States and South Africa have the lion's share. The report estimates that the amount of uranium available at a sensible price-less than $\$ 10$ per lb of $\mathrm{U}_{3} \mathrm{O}_{8}$-is about 7,000 short tons, with a further 126,000 short tons available as by-products of other industrial processes. For a higher price, of course, much more is available. In the range between $\$ 10$ and $\$ 30$ per lb, there are probably a further $1,400,000$ short tons. For comparison, the US Atomic Energy Commission estimated in 1966 that the probable world demand for $\mathrm{U}_{3} \mathrm{O}_{8}$ would be 65,000 short tons by 1980 . Assured reserves at a fair price probably therefore represent ten to fifteen years supply, and the estimate means that annual production will have to be more than trebled by 1980 .

All this is going to make uranium mining a growth industry over the next ten years. On the face of it, there is no great cause for alarm-large areas of the world have yet to be thoroughly prospected, and little is known in the West about reserves in Communist countries. The sea may also provide an alternative source of uranium, and the United Kingdom Atomic Energy Authority has estimated that the sea contains some 4,000 million tons of the mineral. This could be extracted at a price, although it seems to be too great a price to make the process immediately attractive. Technological development will also help, and the most important element in this is likely to be fast breeder reactors, which will make much better use of uranium-238, converting it to plutonium and burning that as fuel. While modern water reactors reflect a dollar increase in the price per $\mathrm{lb}$ of $\mathrm{U}_{3} \mathrm{O}_{8}$ by an increase in generation cost of 0.08 mill per $\mathrm{kWh}$, fast breeders will be less sensitive to raw material costs.

\section{Science School}

THe Science Foundation for Physics within the University of Sydney is to hold its second International Science School for high school students from August 26 to September 6 this year. The school, directed by Professor H. Messel, who first conceived the idea, will be on the general theme, "Man in Inner and Outer Space". Twenty students from the United States, Japan and Britain will join one hundred and four students from Australia and New Zealand for the course of twenty lectures given by Australian and overseas scientists-seven of the lectures, for some reason, will be on America's projected manned Moon landing.

Overseas scholarships were first offered last year to ten American students. This year is the first time that the scholarships have been extended to Britain and Japan. The ten American students will once again receive their awards personally from President Johnson. Similarly, the Japanese Prime Minister, Mr Eisaku Sato, will sponsor the five Japanese representatives. The British students, on the other hand, will have to be content with the Royal Institution, under the patronage of the Duke of Edinburgh. The five British recipients of the scholarships will be known as the "Royal Institution Australian Science Scholars". The five lucky students were chosen from schools all over the country with the assistance of the Association for Science Education. All the winners will get a round-the-world air ticket with a two-week stay in Sydney for the Science School.

\section{More Chemists Needed}

How is industry to attract its fair share of science graduates? The chemical industry is tackling this problem by organizing a conference with the theme "Modern Chemistry in Industry", to be held at Eastbourne between March 11 and 14. An attendance of about 1,000 is expected at the conference, including representatives from industry, government and the trade unions, but the majority will be science teachers and lecturers from the schools and universities.

The problem to be faced is two-fold-the flow of school leavers into the sciences needs to be increased, and more graduates must be encouraged to work in industry. The organizers of the conference point to a lack of balance in the educational system. The drift away from science in the schools continues, leaving unfilled places in university science departments, while the arts faculties are having to turn away highly qualified candidates. Even if the school leaver can be persuaded to enter a university science department, he is likely to fall prey to the notion widespread among graduates that research by industrial organizations is in some way inferior to that done in the universities. 